JAMP: Jurnal Adminitrasi dan Manajemen Pendidikan

Volume 5 Nomor 1 Maret 2022, Hal : 77 - 86

Tersedia Online di http://journal2.um.ac.id/index.php/jamp/

ISSN 2615-8574 (online)

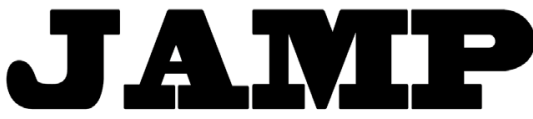

JURNAL ADMINISTRASI DAN MANAJEMEN PENDIDIKAN

\title{
IMPLEMENTASI KEPEMIMPINAN PEMBELAJARAN UNTUK MEWUJUDKAN MUTU SEKOLAH
}

\author{
Moh. Rizal Bafadal, Erny Roesminingsih, Meini Sondang Sumbawati \\ Program Studi S2 Manajemen Pendidikan Universitas Negeri Surabaya \\ Jalan Lidah Wetan Surabaya 60213 \\ E-mail: mohrizal.20025@mhs.unesa.ac.id Telp:087865921403
}

\begin{abstract}
The objectives of this study are to analyze and describe the implementation of instructional leadership to achieve the quality of SMK Darul Kamal NW Kembang Kerang. The method used is qualitative approach with a case study. The data and information are gained through observation, interview, and documentation. The result of the research in SMK Darul Kamal NW Kembang Kerang showed that instructional leadership was implemented well through maximum learning followed by extracurriculars (compulsory and specialization), so the school's quality can be achieved.
\end{abstract}

Keywords: implementation; instructional leadership; school's quality

\begin{abstract}
Abstrak: Tujuan penelitian ini adalah untuk menganalisis dan mendeskripsikan implementasi kepemimpinan pembelajaran untuk mewujudkan mutu SMK Darul Kamal NW Kembang Kerang. Metode yang digunakan ialah pendekatan kualitatif dengan jenis studi kasus. Data dan informasi diperoleh dari hasil pengamatan, wawancara, dan dokumentasi. Hasil penelitian di SMK Darul Kamal NW Kembang Kerang ini menunjukkan bahwa kepemimpinan pembelajaran telah diimplementasikan dengan baik melalui pembelajaran yang maksimal yang didukung dengan kegiatan ekstrakurikuler (wajib dan peminatan) sehingga mutu sekolah dapat diwujudkan.
\end{abstract}

Kata kunci: implementasi; kepemimpinan pembelajaran; mutu sekolah

pendidikan yang berkualitas menjadi topik penting saat ini lebih-lebih pada era globalisasi yang penuh tantangan dan persaingan. Kualitas atau mutu sangat menentukan keberadaan sebuah lembaga pendidikan sebagai wadah layanan jasa bagi masyarakat. Berkenaan dengan mutu terdapat berbagai definisi dari sudut pandang yang berbeda. Feigenbaum (Amin, 2019) berpendapat bahwa mutu atau kualitas melingkupi kepuasan pada pelanggan. Sedangkan menurut Elliot (Juliansyah, 2012) menegaskan bahwa mutu merupakan sesuatu yang berbeda tergantung dari tempat, waktu, tujuan, dan orang yang berbeda pula. Standarisasi mutu dalam dunia pendidikan di Indonesia diatur menjadi pedoman bagi seluruh sekolah tanpa kecuali agar layanan jasa pendidikan betul-betul bermanfaat bagi masyarakat selaku pengguna jasa pendidikan. Standar mutu pendidikan yang dimaksud telah diatur dalam pasal 1 ayat 1 Peraturan Pemerintah Nomor 32 Tahun 2013 menyebutkan bahwa standar mutu pendidikan mencakup 8 standar, antara lain: Standar pembiayaan, standar sarana-prasarana, standar tenaga pendidik dan kependidikan, standar pengelolaan, standar proses, standar isi, standar kompetensi kelulusan, dan standar penilaian pendidikan (Peraturan Pemerintah No.32, 2013).

Berbicara tentang mutu sekolah erat hubungannya dengan kepemimpinan. (Rahmawati \& Supriyanto, 2020) menjelaskan bahwa tercapainya tujuan dalam sebuah organisasi atau lembaga bergantung pada pemimpin yang mampu menggerakkan, mendorong, dan menyemangati bawahannya. Hasil berbagai riset diantaranya yang telah dilakukan oleh Manullang (2015) dan Hamel (2021) hasilnya menunjukkan bahwa gaya kepemimpinan yang paling efektif dalam mewujudkan mutu lembaga pendidikan adalah kepemimpinan pembelajaran. 
Sesungguhnya kepemimpinan pembelajaran telah cukup lama dikembangkan oleh para ahli dengan beberapa model pengaplikasiannya. Hallinger \& Murphey (1985) mengembangkan tiga model dalam penerapan kepemimpinan pembelajaran di sekolah, diantaranya: Penyusunan misi sekolah, kondusifitas lingkungan belajar, dan pengembangan pembelajaran. Model berikutnya diutarakan oleh Murphy (1990) bahwa terdapat empat dimensi kepemimpinan pembelajaran diantaranya: Pengelolaan pembelajaran, pengembangan misi dan tujuan lembaga pendidikan, lingkungan kerja yang memadai, dan iklim sekolah yang mendukung. Kaitannya dengan hal tersebut Weber (1996) telah mengembangkan beberapa dimensi kepemimpinan pembelajaran, diantaranya: Pengembangan misi sekolah, mengelola dan mengobservasi kurikulum termasuk pembelajaran, melakukan penilaian, dan menciptakan iklim belajar yang nyaman.

Bila dimensi-dimensi kepemimpinan pembelajaran berjalan, maka terwujudlah mutu suatu sekolah sehingga mampu bersaing dengan sekolah lainnya. Upaya peningkatan mutu sekolah harus memiliki pijakan yang kuat. Astuty (2014) telah meringkas prinsip-prinsip yang menjadi landasan sebuah lembaga pendidikan dalam mewujudkan mutu yang tertuang dalam Sistem Manajemen Mutu ISO 9001:2008, diantaranya: kepemimpinan, fokus pada pelanggan, keterlibatan seluruh personil, adanya pendekatan proses, terdapat pendekatan sistem pada manajemen, keputusan diambil melalui pendekatan fakta, adanya interaksi saling menguntungkan dengan pemasok, dan terdapat peningkatan secara berkesinambungan.

Landasan pentingnya kepemimpinan pembelajaran di Indonesia tertuang dalam Peraturan Menteri Pendidikan dan Kebudayaan Republik Indonesia Nomor 6 Tahun 2018 yang menegaskan tugas pokok kepala sekolah. Adapun tugas kepala sekolah menurut peraturan yang dimaksud ialah tugas manajerial dan supervisi termasuk pembimbingan dalam kegiatan pembelajaran yang diarahkan untuk pengembangan dan peningkatan mutu sekolah (Kementerian Pendidikan dan Kebudayaan Republik Indonesia, 2018).

Masyarakat sebagai pelanggan dalam layanan jasa pendidikan mulai peka terhadap kualitas lembaga pendidikan yang kerap dikaitkan dengan berjalannya kepemimpinan seorang kepala sekolah. Kepedulian dan penilaian orang tua peserta didik sangat berguna bagi kemajuan sekolah (Malindo dkk, 2020). Penilaian ini terjadi tak terkecuali oleh masyarakat yang menyekolahkan anaknya di SMK Darul Kamal NW Kembang Kerang. Fenomena ini tentu harus terjawab seiring dengan upaya memenuhi standar komponen-komponen mutu yang telah ditetapkan pemerintah. Lembaga pendidikan menyandang kategori bermutu bila diakui oleh pemerintah yang berperan sebagai pengendali dan penjamin mutu pendidikan (Fadhli, 2017).

Kondisi SMK Darul Kamal NW Kembang Kerang yang bernaung pada sebuah yayasan swasta dan berada di tempat yang tergolong daerah pelosok dengan fasilitas yang masih terbatas. Hal tersebut tidak menyurutkan semangat warga sekolah untuk terus berbenah dan melaksanakan program-program strategis dengan mengedepankan nilai-nilai keagamaan yang tumbuh dan berkembang pada yayasan dengan tujuan sebagai upaya perbaikan mutu serta demi kemajuan sekolah. Kemauan dan semangat yang kuat dapat membawa kemajuan pada suatu sekolah (Wisda, 2021). Kepala sekolah bersama warga sekolah secara terus menerus berupaya meningkatkan mutu sekolah mengingat keberlangsungan sekolah pada masa mendatang sangat bergantung pada keberadaan atau tingkat capaian mutu. Hal inilah yang menjadi wujud tanggung jawab sekolah secara menyeluruh terhadap proses pendidikan. Septiana, dkk (2018) menjelaskan tentang upaya mewujudkan mutu sekolah bertujuan mengarahkan sekolah sebagai lembaga yang mengedepankan layanan pendidikan dengan penuh rasa tanggung jawab bagi peserta didik dan umumnya bagi masyarakat.

Secara lebih spesifik orang tua peserta didik dan masyarakat pada umumnya menilai prestasi belajar peserta didik menjadi tolok ukur keberhasilan sekolah. Hal tersebut menjadi tantangan yang harus dihadapi oleh pihak sekolah. Berbagai upaya dilakukan oleh SMK Darul Kamal NW Kembang Kerang dalam mendorong peningkatan prestasi belajar siswa. Keberadaan seorang kepala sekolah menjadi faktor utama dalam upaya tersebut ditunjang dengan tenaga pendidik yang memiliki kompetensi dibarengi dengan standar kurikulum yang memadai serta adanya pembelajaran yang berjalan sesuai dengan harapan. Bila hal-hal yang menunjang tersebut terpenuhi maka terwujudlah proses dan hasil belajar peserta didik yang meningkat dari waktu ke waktu. Peningkatan mutu dalam suatu lembaga pendidikan mencerminkan dua sudut pandang yang harus seimbang yaitu mutu dilihat dari proses dalam pendidikan dan mutu dilihat dari sisi hasil dari pendidikan (Ambarita, 2009). 
Meskipun pembelajaran telah dilaksanakan secara maksimal faktanya prestasi belajar peserta didik masih perlu untuk ditingkatkan. Hal ini terjadi mengingat terbatasnya waktu dan pembimbingan terhadap peserta didik dalam kegiatan pembelajaran yang diselenggarakan hanya pada pagi hingga siang hari. Berangkat dari masalah tersebut kepala sekolah bersama bawahannya menyusun dan melaksanakan kegiatan ekstrakurukuler sebagai langkah strategis untuk mendukung kegiatan akademik yang dimaksudkan untuk mengembangkan bakat dan minat peserta didik serta menambah pengetahuan dan keterampilan yang bermuara pada peningkatan prestasi belajar peserta didik.

Kegiatan ekstrakurikuler yang didesain di luar jam pembelajaran yaitu pada siang sampai sore hari juga sebagai wujud kepala sekolah menggerakkan sumber daya para pendidik. Kompetensi yang dimiliki oleh tiap-tiap pendidik digali kemudian diberdayakan dalam pembinaan kegiatan tersebut. Sebagai bentuk penguatan dan memastikan pelaksanaan kegiatan yang dimaksud kepala sekolah melakukan kegiatan monitoring dan evaluasi secara periodik. Kaitannya dengan upaya tersebut menjadi bagian dari terimpelementasinya dimensi kepemimpinan pembelajaran yang telah penulis dikemukakan menurut pendapat para ahli sebelumnya bahwa pemimpin pembelajaran memiliki kemampuan dalam mengelola sumber daya yang ada di sekolah sebagai upaya mewujudkan mutu sekolah.

Adapun kegiatan ekstrakurikuler yang telah disepakati dan dilaksanakan secara maksimal di SMK Darul Kamal NW Kembang Kerang terbagi menjadi dua yaitu ekstrakurikuler wajib dan ekstrakurikuler peminatan. Ekstrakurikuler wajib yang diwajibkan kepada peserta didik mencakup: tartil dan tahfidz AlQur'an, english club, desain grafis, serta jurnalistik dan persuratan. Sementara itu pada ekstrakurikuler peminatan, peserta didik diberi kebebasan untuk mengikuti kegiatan majalah dinding dan kegiatan pecinta alam.

Pelaksanaan pembelajaran dan pelaksanaan kegiatan ekstrakurikuler yang maksimal di SMK Darul Kamal NW Kembang Kerang menjadi hal yang sangat menonjol baik diantara lembaga-lembaga pendidikan yang berada di lingkungan Yayasan Darul Kamal NW Kembang Kerang maupun di luar yayasan tersebut. Hal ini menjadi sangat unik dan menarik dan mendapat tanggapan yang sangat positif dari masyarakat mengingat hampir setiap hari tercipta suasana belajar di sekolah dari pagi sampai siang hari dimaksimalkan untuk kegiatan pembelajaran dan pada siang sampai sore hari diselenggarakan kegiatan ekstrakurikuler. Dengan demikian hal ini peneliti anggap sebagai gejala berjalannya kepemimpinan pembelajaran.

Sehubungan dengan hal tersebut peneliti bermaksud melakukan penelitian tentang impelementasi kepemimpinan pembelajaran kepala sekolah dalam mewujudkan mutu SMK Darul Kamal NW Kembang Kerang. Penelitian ini dianggap urgen mengingat keberhasilan tenaga pendidik meningkatkan prestasi belajar siswa pada sebuah sekolah sangat bergantung pada implementasi kepemimpinan pembelajaran. Hasil penelitian sebelumnya, Tanama, dkk (2017) secara spesifik membuktikan bahwa kepemimpinan pembelajaran dapat meningkatkan prestasi belajar peserta didik.

Penelitian ini bertujuan untuk mengetahui sejauh mana implementasi kepemimpinan pembelajaran oleh kepala sekolah dengan menggerakkan sumber daya yang ada di sekolah untuk memaksimalkan pembelajaran yang didukung dengan kegiatan supervisi dan berbagai kegiatan ekstrakurikuler yang disertai dengan kegiatan monitoring dan evaluasi kepala sekolah. Upaya tersebut diharapkan dapat membawa peningkatan prestasi belajar peserta didik sebagai wujud mutu SMK Darul Kamal NW Kembang Kerang.

\section{METODE}

Metode yang digunakan dalam penelitian mengenai penerapan kepemimpinan pembelajaran guna mewujudkan mutu sekolah ini adalah metode kualitatif dengan jenis studi kasus. Pengambilan data dan informasi dari kegiatan dalam kurun waktu tertentu mencirikan penelitian studi kasus (Creswell \& Creswell, 2018). Dengan pendekatan ini peneliti menganalisis kemudian mendeskripsikan secara komprehensif implementasi kepemimpinan pembelajaran dan peningkatan mutu SMK Darul Kamal NW Kembang Kerang. Data dan informasi diperoleh melalui pengamatan terhadap kegiatan di sekolah 
yang dipadukan dengan hasil wawancara peneliti terhadap para informan kemudian dilengkapi dengan dokumentasi sekolah. Kata-kata dan tindakan informan menjadi sumber data dilengkapi dokumen lainnya Moleong (2019). Mengikuti pendapat Sugiyono (2021) informan yang dipilih oleh peneliti ialah orang yang dianggap sebagai penentu kebijakan pada SMK Darul Kamal NW Kembang Kerang (purposive sampling) yaitu kepala sekolah namun setelah peneliti menggali data dan informasi hasilnya belum lengkap sehingga dipilih lagi informan-informan yang lain yaitu wakil kepala sekolah bidang kurikulum, beberapa guru, dan tenaga kependidikan (snowball sampling).

Peneliti menggunakan lembar pengamatan dan instrumen wawancara yang tersusun untuk mengumpulkan data dan informasi disertai catatan-catatan hasil di tempat penelitian. Alat bantu yang digunakan untuk mendokumentasikan dan merekam wawancara saat penelitian berupa handphone. Selanjutnya data dan informasi dikumpulkan untuk diolah dan disesuaikan dengan fokus dan tujuan penelitian ini melalui tiga teknik analisis data diantaranya: kondensasi data, penyajian data, dan penarikan kesimpulan (Miles, et al. 2014). Agar data dan informasi betul-betul dapat dipercaya maka harus melalui pengujian keabsahan data. Riyanto (2007) Menyebutkan 4 standar pengujian tersebut antara lain: dependability, credibility, transferability, dan conformability.

\section{HASIL DAN PEMBAHASAN}

Impelementasi kepemimpinan pembelajaran di SMK Darul Kamal NW Kembang Kerang menjadi bagian fokus utama dari penelitian ini. Selanjutnya kepala sekolah menggerakkan seluruh warga sekolah untuk memaksimalkan kegiatan pembelajaran. Komitmen bersama untuk meningkatkan prestasi belajar peserta didik selain dari dimaksimalkannya pembelajaran, juga didukung dengan pelaksanaan kegiatan ekstrakurikuler. Upaya kepala sekolah sebagai sosok pemimpin pebelajaran mampu mengefektifkan kegiatan pembelajaran dan ekstrakurikuler sebagai upaya mewujudkan mutu sekolah.

Indikator keberhasilan penerapan kepemimpinan pembelajaran di SMK Darul Kamal NW Kembang Kerang telah dicapai. Kepala sekolah mengarahkan setiap kegiatan yang dilakukan oleh warga sekolah menuju pencapaian misi dan tujuan sekolah yang telah disepakati bersama. Kepala sekolah selalu memotivasi warga sekolah akan pentingnya peningkatan prestasi belajar. Arahan dan dorongan kepala sekolah sebagai bentuk implementasi kepemimpinan pembelajaran dan berkontribusi terhadap peningkatan prestasi belajar peserta didik (kode P: pengamatan dan kode W.KS.WKS.G.TK: wawancara dengan kepala sekolah, wakil kepala sekolah bidang kurikulum, guru, dan tenaga kependidikan).

Kegiatan pembelajaran yang bermutu diawali dengan penyusunan dan pengaplikasian Rencana Pelaksanaan Pembelajaran (RPP). Suasana kelas yang menyenangkan menggiring setiap peserta didik aktif bertanya dan menjawab baik kepada gurunya maupun sesama peserta didik. Pembelajaran menjadi lebih menantang dan menggali minat serta bakat peserta didik seiring dengan perkembangan fisik dan psikologinya. Para tenaga pendidik membuka kesempatan kepada peserta didik untuk menunjukkan kreativitas dan kemandiriannya (kode P: pengamatan).

Kepala SMK Darul Kamal NW Kembang Kerang memfasilitasi tenaga pendidik baik dalam menyusun perencanaan maupun pelaksanaan pembelajaran. Supervisi akademik dilakukan guna membantu bawahannya dengan memberikan masukan dan saran perbaikan. Di samping itu agar perencanaan dan pelaksanaan pembelajaran berjalan maksimal, kepala sekolah menyelenggarakan supervisi teman sejawat (kode P: pengamatan dan W.WKS.G: wawancara dengan wakil kepala sekolah bidang kurikulum dan guru).

Dokumen hasil supervisi Kepala SMK Darul Kamal NW Kembang Kerang mendeskripsikan RPP yang dikembangkan telah lengkap dan sistematis serta memperhatikan kebutuhan peserta didik yang telah diterapkan dengan baik dalam proses pembelajaran (kode D: Dokumentasi). Hasil wawancara peneliti dengan kepala sekolah menguatkan hasil supervisi akademik yang menunjukkan selarasnya perencanaan dengan pelaksanaan pembelajaran (kode W.KS: wawancara dengan kepala sekolah).

Pembelajaran di luar sekolah juga telah dimaksimalkan oleh kepala sekolah bersama bawahannya. Praktik Kerja Industri (PRAKERIN) yang diikuti oleh peserta didik didampingi secara maksimal pada 
perkantoran dan dunia usaha. Adapun tempat-tempat praktik pengalaman kerja bagi peserta didik itu antara lain: kantor pemerintahan, stasiun televisi, dan perusahaan-perusahaan milik daerah maupun swasta (kode P: pengamatan dan D:dokumentasi).

Walaupun pembelajaran telah dilakukan secara maksimal namun kenyataannya belum sepenuhnya dapat meningkatkan prestasi belajar peserta didik. Analisa dan evaluasi kepala SMK Darul Kamal NW Kembang Kerang menunjukkan bahwa pembelajaran dari sisi waktu dan pembimbingan terbatas. Hal ini mendorong kepala sekolah bersama bawahannya menyusun program strategis dan paling efektif serta mendukung dalam upaya tersebut ialah kegiatan ekstrakurikuler (kode P: pengamatan dan kode W.KS.WKS.G.TK: wawancara dengan kepala sekolah, wakil kepala sekolah bidang kurikulum, guru, dan tenaga kependidikan).

Kepala sekolah bersama bawahannya menyusun program pembinaan ekstrakurikuler dengan memperhatikan kompetensi tiap-tiap pendidik. Kegiatan yang diselenggarakan mulai siang hingga sore hari tersebut terbagi dalam dua jenis yaitu: kegiatan ekstrakurikuler wajib (tartil dan tahfidz Al-Qur'an, english club, desain grafis, serta jurnalistik dan persuratan) dan kegiatan ekstrakurikuler peminatan yaitu majalah dinding dan pecinta alam (kode W.KS: wawancara kepala sekolah dan D: dokumentasi).

Kegiatan ekstrakurikuler yang diselenggarakan secara konsisten di SMK Darul Kamal NW Kembang Kerang membawa peningkatan prestasi belajar yang cukup menonjol dalam beberapa mata pelajaran. Kegiatan tartil dan tahfidz Al-Qur'an meningkatkan hasil belajar pada mata pelajaran Pendidikan Agama, english club meningkatkan hasil belajar pada mata pelajaran Bahasa Inggris. Hasil belajar pada jurusan multimedia meningkat dengan adanya kegiatan desain grafis serta hasil belajar pada mata pelajaran Bahasa Indonesia meningkat dengan adanya kegiatan majalah dinding serta kegiatan jurnalistik dan persuratan. Kegiatan pecinta alam juga berkonstribusi pada mata pelajaran Ilmu Pengetahuan Alam. Selain itu, prestasi belajar peserta didik pada mata pelajaran yang lain juga dinilai meningkat dengan terlaksananya berbagai kegiatan ekstrakurikuler tersebut (kode W.KS.WKS.G.TK: wawancara dengan kepala sekolah, wakil kepala sekolah bidang kurikulum, guru, serta tenaga kependidikan dan D: dokumentasi).

Pembelajaran dan kegiatan ekstrakurikuler yang berjalan maksimal di SMK Darul Kamal NW Kembang Kerang menjadikan sekolah ini sebagai sebuah komunitas belajar yang penuh dengan suasana belajar (learning school). Kepala sekolah sebagai pemimpin pembelajaran telah berhasil menumbuhkan motivasi semua warga sekolah untuk berkonstribusi dalam mengejar prestasi. Usaha yang berkesinambungan yang dilakukan pihak sekolah semata-mata demi terwujudnya mutu sekolah (kode P: pengamatan).

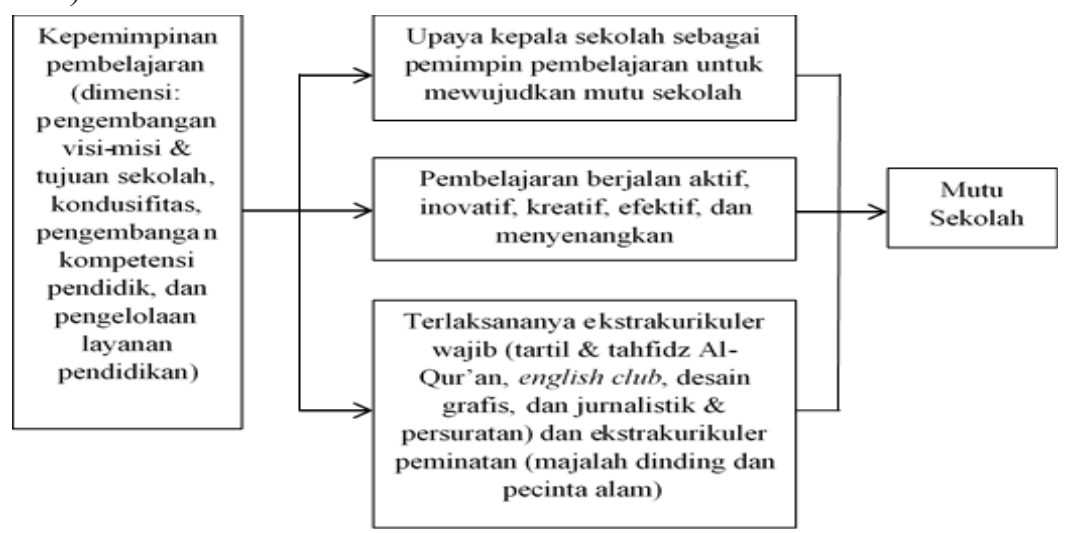

Gambar 1. Upaya mewujudkan mutu SMK Darul Kamal NW Kembang Kerang

Semangat kebersamaan yang dibangun di SMK Darul Kamal NW Kembang Kerang menjadi modal utama dalam meraih mutu sekolah yang lebih baik. Kepala sekolah menggerakkan seluruh sumber daya yang ada. Melalui kewenangannya kepala sekolah memastikan pelaksanaan pembelajaran berjalan secara aktif, inovatif, kreatif, efektif, dan menyenangkan. Kepala sekolah juga secara periodik memantau dan mengevaluasi pelaksanaan kegiatan ekstrakurikuler yang telah dirancang bersama. Komitmen dan rasa 
tanggung jawab dari seluruh warga sekolah ini mewujudkan hasil yang membangggakan berupa prestasi belajar peserta didik yang semakin meningkat.

Adanya peningkatan prestasi belajar peserta didik merupakan wujud pencapaian mutu sekolah. Kepuasan peserta didik dan masyarakat selaku pengguna layanan jasa pendidikan dicapai dari perencanaan, pelaksanaan dan hasil pembelajaran serta pelaksanaan kegiatan ekstrakurikuler (wajib dan peminatan) secara konsisten. Capaian mutu SMK Darul Kamal NW Kembang Kerang menjadikan sekolah ini semakin diminati oleh masyarakat dan mampu bersaing dengan sekolah lain.

Kompetensi kepala SMK Darul Kamal NW Kembang Kerang dalam pengelolaan sumber daya pada lembaga pendidikan yang dipimpinnya menjadi kunci keberhasilan pengembangan visi, misi, dan tujuan sekolah. Pemimpin yang efektif ialah pemimpin yang mampu mengoptimalkan sumber daya pada organisasi yang dipimpinnya (Ulum dkk, 2020). Kompetensi yang dikuasai itu berhasil membawa peningkatan mutu pada sekolah yang dipimpinnya. Peningkatan mutu yang dicapai sekolah menjadi indikator kesuksesan kepala sekolah memimpin dan mengelola lembaganya (Romadhon, 2019).

Lingkungan kerja yang aman dan nyaman pada suatu lembaga pendidikan membawa kepuasan tersendiri bagi pendidik dan kenyamanan peserta didik. Suasana seperti itu telah dibangun oleh kepala SMK Darul Kamal NW Kembang Kerang sekaligus menjadi tolok ukur keberhasilannya dalam berperan sebagai pemimpin pembelajaran. Lingkungan tempat kerja yang baik dan produktif sebagai salah satu indikator kepemimpinan pembelajaran (Wahyudi dkk, 2019).

Pemimpin pembelajaran memprioritaskan peningkatan kompetensi diri dan bawahannya. Hidayat, dkk (2019) menyampaikan bahwa pada era globalisasi saat ini pemimpin organisasi atau lembaga sangat membutuhkan pemimpin yang berkompeten. Kompetensi kepala sekolah dalam pengelolaan program dan konsekuensi penganggaran, peningkatan kinerja pendidik, dan pengembangan budaya organisasi merupakan hal utama kepemimpinan pembelajaran dalam mewujudkan mutu (Hoy \& Miskel, 2013). Pendapat lain tentang kompetensi disampaikan oleh Rosaliawati (2020) bahwa kompetensi guru merupakan salah satu tugas kepala sekolah.

Pengembangan kompetensi pendidik merupakan salah satu langkah strategis yang dilakukan oleh kepala SMK Darul Kamal NW Kembang Kerang dalam memajukan lembaga yang dipimpinnya. Hal ini didukung dengan fasilitas serta pembiayaan yang memadai termasuk tentang kesejahteraannya. Motivasi dan kompetensi tenaga pendidik meningkatkan prestasi belajar peserta didik sebagai implementasi kepemimpinan kepala sekolah (Jamali \& Prasojo, 2013).

Kepala SMK Darul Kamal NW Kembang Kerang melaksanakan kegiatan supervisi sebagai upaya memaksimalkan kompetensi pendidik dalam meningkatkan hasil belajar peserta didik. Hal terpenting yang dilakukan oleh kepala SMK Darul Kamal NW Kembang Kerang ialah menyelaraskan perencanaan pembelajaran harus dengan pelaksanaan pembelajaran ke arah peningkatan mutu sekolah baik dalam hal proses maupun hasil belajar peserta didik. (Dorovolomo dkk, 2010) menyatakan bahwa kualitas pelaksanaan pembelajaran bergantung pada perencanaan pembelajaran yang baik.

Catatan hasil supervisi kepala SMK Darul Kamal NW Kembang Kerang secara obyektif terdeskripsi sejauh mana kompetensi masing-masing tenaga pendidik dalam hal kemampuannya menyusun RPP sesuai prinsip-prinsip yang telah ditetapkan dan pengembangannya dalam proses pembelajaran. Rahayu (2019) berpendapat bahwa RPP yang berkualitas sesuai dengan prinsip-prinsip penyusunannya. Kompetensi tenaga pendidik dapat dicermati dan dinilai dari tahap menyusun program pembelajaran yaitu tenaga pendidik mengembangkan silabus dan rencana pelaksanaan pembelajaran sesuai kurikulum sekolah (Maujud, 2018). Selanjutnya tentang supervisi diungkapkan oleh Andora (2019) yang dikuatkan oleh pendapatnya Putri, dkk (2021) bahwa supervisi sangat berperan meningkatkan kompetensi tenaga pendidik dalam menyusun rencana pembelajaran.

Kegiatan supervisi kepala SMK Darul Kamal NW Kembang Kerang sebagai bentuk bimbingan guna perbaikan ke depannya. Keberhasilan sebuah lembaga tergantung dari pemimpin dan efisiensi bimbingannya (Pawar dkk, 2020). Khusus mengenai pembelajaran diutarakan oleh Usman \& Raharjo (2013)observasi partisipasi, dan dokumentasi. Subjek penelitian adalah kepala sekolah, wakil kepala sekolah, dan anggota komite sekolahsecara snowball. Orang kunci dalam penelitian ini adalah kepala 
sekolah. Objek penelitian adalah pelaku, konsep, tempat, dan kegiatan. Keabsahan data dilakukan dengan kriteria kredibilitas, transferabilitas, dependabilitas, dan komfirmabilitas. Langkah-langkah dan analisis data yang digunakan adalah model Lichman (2011 bahwa upaya yang dilakukan oleh kepala sekolah dalam mewujudkan mutu pembelajaran ialah melalui kunjungan kelas. Disamping itu, kepala sekolah menyelenggarakan kegiatan supervisi teman sejawat di sekolah dengan tujuan mendukung agar pembelajaran berjalan maksimal. Hadi, dkk (2019) menyatakan supervisi teman sejawat bertujuan memperbaiki kualitas perencanaan dan pelaksanaan pembelajaran.

Meskipun bimbingan dan pengendalian oleh kepala SMK Darul Kamal NW Kembang Kerang kepada bawahannya bukan berarti membatasi kreativitas dalam perencanaan dan pelaksanaan pembelajaran demi terwujudnya mutu sekolah yang lebih baik. Kepercayaan kepala sekolah terhadap bawahannya menjadi kunci sekolah yang bermutu (Gemnafle \& Batlolona, 2021). Praktik yang terjadi menurut pengamatan peneliti bahwa kepala sekolah memberikan kesempatan seluas-luasnya kepada bawahannya untuk berkreasi dan berinovasi.

Hasil evaluasi kepala SMK Darul Kamal NW Kembang Kerang menunjukkan bahwa prestasi belajar peserta didik masih perlu ditingkatkan lagi sekalipun pembelajaran dilaksanakan secara maksimal. Hal yang disepakati melalui forum diskusi kepala sekolah bersama pendidik dan tenaga kependidikan ialah tentang penyusunan program ekstrakurikuler yang diharapkan berkonstribusi dalam pengembangan minat dan bakat kemudian sebagai wadah yang efektif guna menambah keterampilan dan pengetahuan sehingga dapat meningkatkan prestasi belajar peserta didik.

Berbagai kegiatan ekstrakurikuler yang dipilih dan disusun pada SMK Darul Kamal NW Kembang Kerang tetap mengedepankan nilai-nilai budaya yang berkembang dalam yayasan tempat sekolah ini bernaung. Kegiatan yang dirancang dan dilaksanakan pada siang hingga sore hari bertujuan untuk mendorong peningkatan prestasi belajar peserta didik. Terdapat beberapa kegiatan ekstrakurikuler yang harus diikuti oleh seluruh siswa dengan harapan agar tujuan untuk meningkatkan prestasi belajar dapat menyentuh seluruh peserta didik, diantaranya: tartil dan tahfidz Al-Qur'an, english club, desain grafis, serta jurnalistik dan persuratan yang selanjutnya disebut ekstrakurikuler wajib. Selain itu, kegiatan yang tak kalah pentingnya dalam mendorong prestasi belajar peserta didik ialah kegiatan ekstarkurikuler pilihan yaitu majalah dinding dan pecinta alam. Kompetensi yang dimiliki oleh tiaptiap pendidik diarahkan untuk pembinaan dan pendampingan peserta didik dalam pelaksanaan kegiatan ekstrakurikuler. Para pendidik terbagi dalam kelompok kegiatan ekstrakurikuler wajib dan peminatan sesuai dengan kompetensinya dengan harapan agar pendidik tetap termotivasi karena pembagian tugas sesuai dengan kompetensinya sehingga kegiatan berjalan maksimal dan berhasil membawa perbaikan terhadap prestasi belajar peserta didik. Mengingat kegiatan ekstrakurikuler diselenggarakan di luar jam pembelajaran yaitu pada siang sampai sore hari, kepala SMK Darul Kamal NW Kembang Kerang bersama bawahannya menyepakati untuk menganggarkan insentif dan pengganti biaya transportasi bagi pembina kegiatan ekstrakurikuler dari dana Bantuan Operasional Sekolah (BOS) sesuai dengan volume kegiatan pembinaan masing-masing agar tetap bersemangat dalam membina kegiatan. Motivasi kerja guru sangat berpengaruh terhadap hasil hasil belajar siswa (Anugrahani, 2021).

Kepala SMK Darul Kamal NW Kembang Kerang selaku pengendali dan penanggung jawab melakukan monitoring dan evaluasi secara berkala terhadap pelaksanaan kegiatan ekstrakurikuler. Kepala sekolah berwenang dan bertanggungjawab terhadap seluruh kegiatan di sekolah (Indrayadi dkk, 2021). Adapun hal-hal yang menjadi fokus pemantauan dan evaluasi kepala sekolah diantaranya: ketepatan waktu yang telah direncanakan, kesesuaian materi, dan tingkat kehadiran baik pendidik sebagai pembina maupun peserta didik. Selanjutnya, kepala SMK Darul Kamal NW Kembang Kerang membuka ruang diskusi kepada pendidik bahkan peserta didik untuk membahas perkembangan pelaksanaan kegiatan. Diskusi diselenggarakan untuk membahas sejauh mana kemajuan dan kelemahan dalam kegiatan ekstrakurikuler. Selanjutnya, bila terdapat kelemahan atau kekurangan disepakati solusi yang terbaik sehingga ke depannya proses dan hasil kegiatan terwujud sesuai harapan.

Seluruh kegiatan di SMK Darul Kamal NW Kembang Kerang diarahkan untuk meningkatkan mutu sekolah. Prestasi belajar peserta didik berangkat dari proses pembelajaran yang maksimal dan didukung 
oleh kegiatan ekstrakurikuler yang dilaksanakan secara konsisten. Mewujudkan sekolah yang bermutu merupakan tujuan utama SMK Darul Kamal NW Kembang Kerang. Bush (2018) menegaskan tujuan sekolah harus menjadi prioritas yang utama. Tujuan yang telah dirancang bersama dapat tercapai sangat ditentukan oleh kepala sekolah dalam mengarahkan dan memfasilitasi seluruh warga sekolah. Semangat kebersamaan tetap dibangun oleh kepala sekolah demi tercapainya tujuan sekolah. Hakikatnya tujuan akhir dari terwujudnya sekolah yang bermutu agar dapat bersaing dengan sekolah lainnya dan tetap mendapat tempat di hati masyarakat.

\section{SIMPULAN DAN SARAN}

\section{Simpulan}

Kepemimpinan pembelajaran di SMK Darul Kamal NW Kembang Kerang telah berjalan dengan baik ditandai dengan seluruh kegiatan diarahkan pada tercapainya visi, misi, dan tujuan sekolah. Kepala sekolah berhasil menciptakan lingkungan belajar yang aman dan nyaman bagi seluruh warga sekolah. Suasana tercipta penuh semangat dan menyenangkan dalam kegiatan pembelajaran.

Meskipun pembelajaran telah dilaksanakan secara maksimal namun dianggap masih belum sesuai harapan dalam upaya peningkatan prestasi belajar peserta didik secara menyeluruh. Berangkat dari hal ini, kepala sekolah bersama bawahannya terus berupaya untuk mencapai harapan bersama tersebut. Langkah yang strategis guna mencapai hal tersebut adalah sekolah menyelenggarakan kegiatan ekstrakurikuler (wajib dan peminatan) dan berhasil mendukung kegiatan pembelajaran sebagai upaya peningkatan prestasi belajar peserta didik.

Peningkatan prestasi yang dimaksud sebagai perwujudan sekolah yang bermutu dan mampu bersaing dengan sekolah lain. Tingginya tingkat kepuasan peserta didik dan orang tua selaku pengguna layanan jasa pendidikan mengantarkan SMK Darul Kamal NW Kembang Kerang menjadi salah satu lembaga pendidikan yang bermutu dan sangat diminati oleh masyarakat.

\section{Saran}

Hasil penelitian pada SMK Darul Kamal NW Kembang Kerang menemukan bahwa kepemimpinan pembelajaran yang diimplementasikan dengan baik dapat mewujudkan mutu sekolah. Kepemimpinan memiliki dimensi yang luas bila dihubungkan dengan upaya mewujudkan mutu sekolah sehingga perlu dieksplorasi lebih lanjut. Temuan penelitian di SMK Darul Kamal NW Kembang Kerang masih terbatas pada sudut pandang kepemimpinan pembelajaran. Oleh karena itu, peneliti merekomendasikan kepada peneliti selanjutnya untuk menggali lebih jauh kajian-kajian dari sudut pandang teori kepemimpinan selain kepemimpinan pembelajaran. Penelitian melalui pendekatan kuantitatif dapat juga dilakukan dengan membuktikan korelasi antara kepemimpinan pembelajaran dengan berbagai variabel.

\section{DAFTAR RUJUKAN}

Ambarita, B. (2009) 'Strategi Perguruan Tinggi dalam Meningkatkan Mutu Pendidikan', Generasi Kampus, 2(1), pp. 21-34. Available at: https://jurnal.unimed.ac.id/2012/index.php/gk/article/view/6948.

Amin, M. F. (2019) 'Mutu dalam Perspektif Fegeinbaum dan Implementasinya dalam Lembaga Pendidikan', Managere : Indonesian Journal of Educational Management, 1(1), pp. 86-98. doi: 10.52627/ijeam.v1i1.10.

Andora, D. (2019) 'Peranan Supervisi dalam Memaksimalkan Kinerja Pendidik', ResearchGate, pp. 1-5. doi: http://dx.doi.org/10.31227/osf.io/nztvm.

Anugrahani, N. A. (2021) 'Pengaruh Kepemimpinan Kepala Sekolah dan Kinerja Guru Terhadap Motivasi Belajar Siswa SMK', JAMP: Jurnal Administrasi dan Manajemen Pendidikan, 4(3), pp. 239-248. doi: http://dx.doi. org/10.17977/um027v4i32021p239.

Astuty, E. (2014) '8 Prinsip Manajemen Mutu dalam Realita Penerapan ISO 9001:2008 di Universitas X Bandung', in Conference: Prosiding Seminar Nasional \& Call for PaperAt: Universitas Kristen Maranatha, Bandung Authors:, pp. 1-15. Available at: https://www.researchgate.net/profile/Eriana-Astuty/ publication/319182668_8 
Bush, T. (2018) 'Transformational leadership: Exploring common conceptions', Educational Management Administration and Leadership, 46(6), pp. 883-887. doi: 10.1177/1741143218795731.

Creswell, W. J., and Creswell, J. D. (2018) Research Design: Qualitative, Quantitative adn Mixed Methods Approaches, SAGE Publications, Inc. Los Angeles. doi: ISBN 978-1-5063-8670-6 (pbk. : alk. paper) Subjects:

Dorovolomo, J., Phan, H. P. and Maebuta, J. (2010) 'Quality lesson planning and quality delivery: Do they relate?', International Journal of Learning, 17(3), pp. 447-455. doi: 10.18848/1447-9494/CGP/v17i03/46955.

Fadhli, M. (2017) 'Manajemen Peningkatan Mutu Pendidikan', TADBIR : Jurnal Studi Manajemen Pendidikan, 1(02), pp. 215-240. doi: http://dx.doi.org/10.29240/jsmp.v1i2.295.

Gemnafle, M. and Batlolona, J. R. (2021) 'Manajemen Pembelajaran', Jurnal Pendidikan Profesi Guru Indonesia (Jppgi), 1(1), pp. 28-42. doi: 10.30598/jppgivol1 issue1 page28-42.

Hadi, A., Nasuka, M. and Munasir (2019) 'Meningkatkan Kinerja Guru Pada Ma Nu Banat Management of Peer Supervision in Improving Teacher' S Performance on Ma Nu Banat Kudus', Jurnal Intelegensia, 07(2), pp. 51-63. doi: https://doi.org/10.34001/intelegensia.v7i2.1279.

Hallinger, P., \& Murphy, J. (1985). Principal Instructional Management Rating Scale (PIMRS). Sarasota: Dr. Philip Halinger.

Hamel, H. C. (2021) 'Peran Kepemimpinan Pembelajaran Kepala Sekolah di SMK YPK Tabernakel Nabire', Cakrawala Ilmu Jurnal Ilmiah Pendidikan, 1(1), pp. 34-44. Available at: https://uswim.e-journal.id/ CakrawalaIlmu/article/view/220.

Hidayat, R., Dyah M, V. and Ulya, H. (2019) 'Kompetensi Kepala Sekolah Abad 21: Sebuah Tinjauan Teoretis', Jurnal Kepemimpinan dan Pengurusan Sekolah, 4(1), pp. 61-68. doi: 10.34125/kp.v4i1.394.

Hoy, Wayne K \& Miskel Cecil G. (2013). Educational Administration: Theory, Research, and Practice. New York: McGraw Hill.

Indrayadi, A. P. et al. (2021) 'Manajemen Berbasis Sekolah pada Komponen Tenaga Kependidikan dan Kesiswaan', JAMP: Jurnal Administrasi dan Manajemen Pendidikan, 4(3), pp. 195-203. doi: http://dx.doi.org/10.17977/ um027v4i32021p195.

Jamali, A. and Prasojo, L. D. (2013) 'Pengaruh Kompetensi Manajerial Kepala Sekolah, Lingkungan, Motivasi Guru, Terhadap Prestasi Siswa SMA Muhammadiyah Kota Yogyakarta’, Jurnal Akuntabilitas Manajemen Pendidikan, 1(1), pp. 8-21. Available at: https://journal.uny.ac.id/index.php/jamp/article/view/2309.

Juliansyah (2012) 'Kritik Filosofis atas Tujuan, Visi, dan Misi Mempertanyakan Mutu Pendidikan Nasional', Jurnal Lentera Bisnis, 1(1), pp. 65-77. doi: http://dx.doi.org/10.34127/jrlab.v1i1.141.

Kementerian Pendidikan dan Kebudayaan Republik Indonesia (2018) 'Peraturan Menteri Pendidikan dan Kebudayaan Republik Indonesia Nomor 6 Tahun 2018 Tentang Penugasan Guru Sebagai Kepala Sekolah’, JDIH BPK RI Database Peraturan, pp. 1-21. Available at: https://lppksps.kemdikbud.go.id/upload/unduhan/ Permendikbud_Nomor6_Tahun2018.pdf.

Malindo, A. V. P., Imron, A. and Sumarsono, R. B. (2020) 'Peningkatan Partisipasi Orang Tua Peserta Didik Berbasis Teknologi Informasi', JAMP: Jurnal Administrasi dan Manajemen Pendidikan, 3(4), pp. 379-388. doi: http://dx.doi.org/10.17977/um027v3i42020p379.

Manullang, J. (2015) 'Pengaruh Kepemimpinan Pembelajaran, Pengetahuan, Manajemen Pendidikan, Komunikasi Interpersonal, dan Kepuasan Kerja Terhadap Komitmen Organisasi Kepala SMA di Kota Medan (Studi Kasus pada SMA di Kota Medan)', Generasi Kampus, 8(1), pp. 33-53. Available at: https://jurnal.unimed. ac.id/2012/index.php/gk/article/view/7134.

Maujud, F. (2018) 'Implementasi Fungsi-Fungsi Manajemen dalam Lembaga Pendidikan Islam (Studi Kasus Pengelolaan Madrasah Ibtidaiyah Islahul Muta’allim Pagutan)', Jurnal Penelitian Keislaman, 14(1), pp. 31-50. doi: 10.20414/jpk.v14i1.490.

Miles, M. B., Huberman, A. M. and Saldana, J. (2014). Qualitative Data Analysis. Amerika: SAGE Publications. Moleong Lexy J. (2019). Metodologi Penelitian Kualitatif, Bandung: Remaja Rosdakarya.

Murphy, J. (1990) Principal instructional leadership. In L.L. Lotto \& P. W. Thurston (Eds), Advances in educational administration: Changing perspectives on the school .(Volume I, Part B, pp. 163-200). Greenwich, CT: JAI Press

Pawar, A. et al. (2020) 'Organizational Servant Leadership: A Systematic Literature Review for Implications in Business', International Journal of Educational Administration, Management, and Leadreship, 1(2), pp. 63-76. doi: 10.51629/ijeamal.v1i2.8. 
Peraturan Pemerintah No.32 (2013) 'Peraturan Pemerintah Republik Indonesia Nomor 32 Tahun 2013 Tentang Standar Nasional Pendidikan', JDIH BPK RI DATABASE PERATURAN, 2(32), pp. 1-52. Available at: https:// peraturan.bpk.go.id/Home/Details/5364/pp-no-32-tahun-2013.

Putri, D. C., Burhanuddin and Wiyono, B. B. (2021) 'JAMP 2 sudah_Supervisi Kepala Sekolah dan Hubungannya dengan Penguasaan Kompetensi Guru SMK', JAMP: Jurnal Ad̄ministrasi dan Manajemen Pendidikan, 4(1), pp. 17-23. doi: http://dx.doi.org/10.17977/um027v4i12021p17.

Rahayu, S. (2019) 'Standar Proses PERMENDIKBUD Nomor 65 Tahun 2019’, INA-Rxiv Papers, (65), pp. 1-15. doi: 10.31227/osf.io/gnmrk.

Rahmawati, S. N. A. and Supriyanto, A. (2020) 'Pentingnya Kepemimpinan dan Kerjasama Tim Dalam Implemeentasi Manajemen Mutu Terpadu’, Jurnal Dinamika Manajemen Pendidikan, 5(1), pp. 1-9. doi: 10.26740/jdmp.v5n1.p1-9.

Riyanto, Yatim, (2007). Metodologi Penelitian Pendidikan Kualitatif dan Kuantitatif: Unesa University Press.

Romadhon (2019) 'Peran Kepala Sekolah Sebagai Manager Dalam Menciptakan Sekolah Efektif di SMP An-Nur Bululawang Malang', Inteligensi : Jurnal Ilmu Pendidikan, 1(2), pp. 8-15. doi: 10.33366/ilg.v1i2.1357.

Rosaliawati, B. N. (2020) 'Hubungan Gaya Kepemimpinan Kepala Sekolah dan Kinerja Guru', JAMP: Jurnal Administrasi dan Manajemen Pendidikan, 3(1), pp. 61-71. doi: http://dx.doi.org/10.17977/ um027v3i12020p61.

Septiana, D. N., Bafadal, I. and Kusumaningrum, D. E. (2018) 'JAMP 3 sudah_Pelibatan Komite Sekolah Dalam Peningkatan Mutu Pendidikan’, JAMP: Jurnal Administrasi dan Manajemen Pendidikan, 1(3), pp. $293-301$. doi: $10.17977 /$ um027v1i32018p293.

Sugiyono, (2021). Metode Penelitian Kualitatif Untuk Penelitian yang bersifat: eksploratif, enterpretif, interaktif, dan konstruktif. Bandung:Alfabeta.

Tanama, Y. J., Bafadal, I. and Degeng, I. N. (2017) 'Pentingnya Kepemimpinan Pembelajaran di Sekolah', Docplayer, pp. 1-7. Available at: https://docplayer.info/49066681-Pentingnya-kepemimpinan-pembelajarandi-sekolah.html.

Ulum, M. B., Sarwoko, E. and Yuniarianto, A. (2020) 'Kepemimpinan Kepala Sekolah dan Kinerja Guru: Peran Mediasi Motivasi Kerja', JAMP: Jurnal Administrasi dan Manajemen Pendidikan, 3(4), pp. 299-307. doi: http://dx.doi.org/10.17977/um027v3i42020p299.

Usman, H. and Raharjo, N. E. (2013) 'Strategi Kepemimpinan Pembelajaran Menyongsong Implementasi Kurikulum 2013', Jurnal Cakrawala Pendidikan, 5(1), pp. 1-13. doi: 10.21831/cp.v5i1.1253.

Wahyudi, A., Narimo, S. and Wafroturohmah (2019) 'Kepemimpinan Pembelajaran Kepala Sekolah dalam Meningkatkan Hasil Belajar Siswa’, Jurnal Varidika, 31(2), pp. 47-55. doi: 10.23917/varidika.v31vi2i.10218.

Weber, J. (1996). Leading the instructional program in Smith SC St Piele PK (eds) School leadership: handbook for excellence. USA: ERIC Clearinghouse on Educational Management.

Wisda, R. S. (2021) 'Persepsi Guru Tentang Kepemimpinan Kepala Sekolah Dasar Negeri', JAMP: Jurnal Administrasi dan Manajemen Pendidikan, 4(4), pp. 358-363. doi: http://dx.doi.org/10.17977/ um027v4i42021p358. 